\title{
ANALYSIS OF STRENGTHENING OF THE FOUNDATIONS OF HISTORIC BUILDING
}

\author{
Elżbieta Kokocińska-Pakiet ${ }^{1 凶}$, Dariusz Bajno² $^{2}$ \\ ${ }^{1}$ Faculty of Civil Engineering and Architecture, Opole University of Technology, Opole \\ 2 Faculty of Civil and Environmental Engineering and Architecture, UTP University of Science and Technology in Bydgoszcz, \\ Bydgoszcz
}

\begin{abstract}
Following the statistics maintained by the National Heritage Board of Poland dated 31 March 2014 currently 183192 monuments have been listed at the territory of Poland. According to the list delivered in 2016 by the Provincial (Opole Province) Monument Conservator, 40 of them are threatened by a construction catastrophe. Some of them require an immediate construction intervention. The statistics show sobering figures but due to a various ownership status and financial situation of the owners unfortunately repairs are not carried out on a regular basis. On the basis of the geological and construction documentation it has been examined the settlement of one of the sacral monuments in Opole Province that was formed throughout centuries. The stage I has covered the analysis of the behaviour of the original foundation of a church settled on a slope. The stage II has embraced the analysis of the foundation that was strengthened and the slope that was secured by a brick retaining wall. The last III stage of calculations has been devoted to the foundations of the structure after being reinforced and the retaining wall strengthened by concrete reinforced coating and a palisade of micropiles anchored to the wall. The main focus has been put on limit equilibrium methods. On the basis of the results the slope and structure stability has been estimated. As to preserve the historic building for future generations the direction of further conservatory works has been determined.
\end{abstract}

Key words: monument, settlement analysis

\section{INTRODUCTION}

The sacral buildings after residential buildings are the second large group of immovable monuments in Poland. Following the data of the Institute for Catholic Church Statistics as of 2011 in Poland 33466 immovable monuments were owned by the Catholic parishes. According to the data mentioned above about $69 \%$ of buildings or some part of them has been reported to the register of monuments (Central Statistical Office, 2014).

The largest number of monuments that require complete renovations appear to be in Lower Silesia Province -249 buildings (14.0\%). The second largest group in said respect is Opole Province -226 buildings $(12.7 \%)$. However, the percentage of buildings that require complete renovation in our Province is definitely the highest (Central Statistical Office, 2014).

\footnotetext{
凶e.kokocinska-pakiet@po.opole.pl
} 


\section{HISTORICAL BACKGROUND}

One of the monuments in Opole Province which underwent repair and conservatory works is the Church of Saint George in Prószków (Fig. 1). On 12 July 1954 the church was entered into the register of monuments of Opole Province (Bajno, 2014). The building of the St. George Church in Prószków dates from 1578. It was founded by the Baron Jerzy Prószkowski. Around the church building a parish, school and hospital were also built (Bajno, 2013).

In 1644 due to warfare the church building was damaged and in 1687 it was rebuilt. The orientation of the new building was changed into the east-west direction. The architect and builder of the church was Jan Seregno and his sons: Antoni and Dominik. The structure was repaired for the first time in 1735 , the church building was anchored peripherally at that time. The anchoring was employed due to numerous cracks of vaults and walls that had appeared. At the end of 19th century (1897-1898) when the problem of cracks in the building reoccurred the anchoring was installed once again. That time also a brick retaining wall was built surrounding the church square and a new high fence was put. Meanwhile at the beginning of the $19^{\text {th }}$ century (about 1817) the dome of the church tower was exchanged. The old damaged roof framework was replaced with the new one, which was covered with copper sheeting. During the repairing works conducted at the beginning of $20^{\text {th }}$ century further numerous scratches and cracks were noticed. In 1904 a technical evaluation was prepared. In the evaluation it was stated that further operation of the building was dangerous and on 31st January the same year the building was closed. In light of deteriorating technical condition of the church it was decided to remove it and build a new object in a different place. Against such decision were Opole administration authorities and the parishpriest. After all it was decided to rescue the building. It was estimated that the main problem was the settlement of the building therefore a ground design of strengthening its foundations was developed. The existing masonry (brick) foundations were the remainings of the $17^{\text {th }}$ century structure and in the opinion of the authors of the evaluation (in 1904) they were too narrow in order to transfer the loads from the walls of that building (Chronicle, 1907; Paluch \& Załeski, 1964). It was decided to strengthen them entirely with concrete slabs (according to the records of historical materials). The works were to be conducted in stages under the entire building in accordance with the instructions. The evaluation assumed excavation around the building and removal of the elements of the brick foundations and supplementation with concrete. The works were completed in 1907, albeit the settlement of the church building eventually was not delivered in a

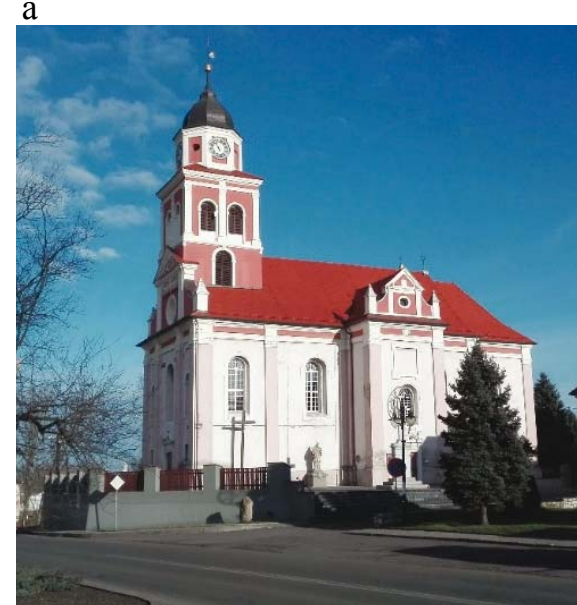

b

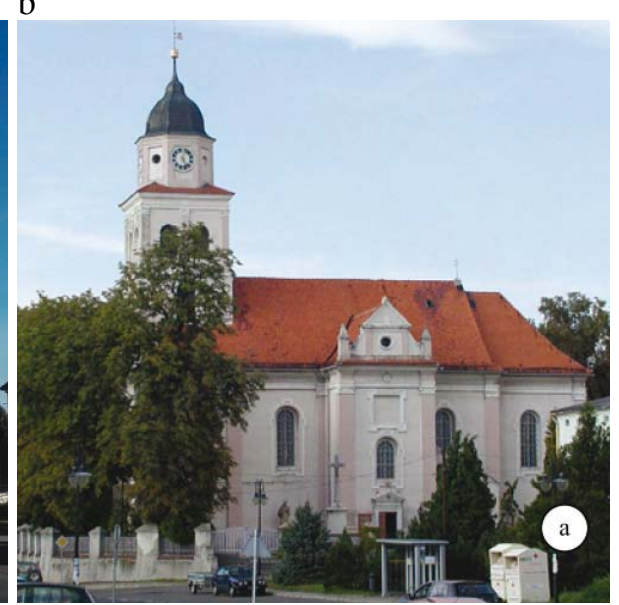

Fig. 1. Saint George Church's view: a - 2018 (photo by E. Kokocińska-Pakiet), b - 2008 (Bajno \& Bednarz, 2010 photo by D. Bajno) 
a concrete but in a masonry version (Chronicle, 1907). The opinion executed in 1964 which held a description of two foundation uncovers corroborated that the settlement of the church building had been strengthened with the use of solid glazed brick bound with cement mortar (Paluch \& Załęski, 1964).

\section{GEOLOGY OF THE CHURCH AREA}

Prószków is a town located about $8 \mathrm{~km}$ south of Opole at Province road 414 Opole - Prudnik. Geographically Prószków is situated in the Opole Plain that belongs to Silesian Lowlands. Prószków situated from 170 to $200 \mathrm{~m}$ above sea level stretches out at a plain area. The area rises from Pomologia, near the church through the market square towards the castle and lowers down again towards the south and west and partially to the east. Through the western part of the town flows Potok Prószkowski (Pozzi, Mizyk, Łozińska \& Adamczyk, 2008).

The parish area and the entire Prószków market square are situated on a slight hill from 176 to $181 \mathrm{~m}$ above sea level in the southern part of the market square. According to archival data the church is located on an artificially formed slope at about $180 \mathrm{~m}$ above sea level. On the basis of the boreholes up to $5 \mathrm{~m}$ below ground level and geological tests executed at the area around the church two geotechnical layers were found: I - sandy clays and sandy gravel (embankment), II - clay and clay with marl. During geological laboratory tests the following parameters of the respective layers were determined - Table 1 (Pozzi, Mizyk, Łozińska \& Adamczyk, 2008).

The subsoil consists of elastic coherent layers. Loams and clays as a result of irrigation may become even more elastic. Soils cumulated in the ground from the hydro geological point of view belong to the group of soils that are hardly permeable or practically nonpermeable. Such soils do not transfer water and only indicate water absorbability. When the soil damping increases the durability parameters exacerbate (soil bearing capacity lowers). Aquifers or saturated soils occur below 4-5 m below ground level. In direct ground there are no aquifers or watered layers (Pozzi, Mizyk, Łozińska \& Adamczyk, 2008).

On account of the building class (I grade monument) the church and related outbuildings are classified as buildings of geotechnical category 3 .

\section{CALCULATIONS}

Assumptions: In the paper it has been discussed the least favourable intersection (northern and western part of the church - Fig. 2), according to the load list

Table 1. Geotechnical parameters of soils (Pozzi, Mizyk, Łozińska \& Adamczyk, 2008)

\begin{tabular}{lcc}
\hline & \multicolumn{2}{c}{ Geotechnical layer } \\
\cline { 2 - 3 } Geotechnical parameters & $\mathrm{I}$ & $\mathrm{II}$ \\
\cline { 2 - 3 } & $\begin{array}{c}\text { sandy clays and sandy gravel } \\
\text { (construction embankment) }\end{array}$ & clay and clay with marl \\
\hline Angle of internal friction $-\varphi\left[^{\circ}\right]^{\mathrm{a}}$ & 13.68 & 8.46 \\
\hline Cohesion $-c[\mathrm{kPa}]^{\mathrm{a}}$ & 14.3 & 42.3 \\
\hline Bulk density/specific $-\rho_{d} / \rho_{s}\left[\mathrm{~g} / \mathrm{cm}^{3}\right]$ & $2.07 / 2.65$ & $1.85 / 2.71$ \\
\hline Oedometer modulus $-E_{o}[\mathrm{MPa}]^{\mathrm{b}}$ & 25.201 & $-/ 0.34$ \\
\hline Soil condtion $-I_{d} / I_{L}$ & $-/ 0.27$ & \\
\hline a $\begin{array}{l}\text { The determination was made in a direct shear apparatus in accordance with the standards PN-B-0448:1989, PN-B-04482:1989, } \\
\text { PN-B-04483: } 1989 . \text { Five degrees of loading were applied at a shear rate of } 0.01 \mathrm{~mm} / \text { min after half-hour consolidation of the } \\
\text { sample. }\end{array}$ & \\
b Read from CPTU survey. &
\end{tabular}




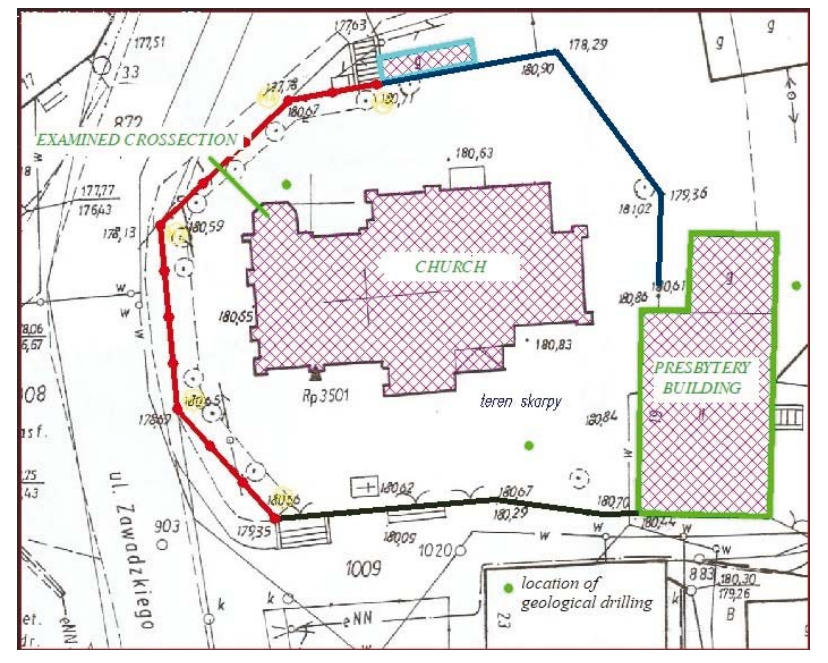

Fig. 2. The location of the church building (prepared by D. Bajno, E. Kokocińska-Pakiet). Deployment of the retaining wall and geological boreholes

the most loaded from the bell tower side. The focus has been on the interaction of the structure and the slope. Mainly, the slope stability has been examined at various periods of the church operation. It has been selected such changes to the structure that had impact on the church settlement and the changes that aimed to strengthen the slopes. The process of strengthening the building was divided into three stages. At each stage the slope stability has been inspected by employment of limit equilibrium methods.

During the respective stages the works embraced the following changes:

1. At the first stage (Fig. 3) - 1687 - the church was rebuilt in the new Baroque style, at the old foundations the orientation of the church was changed. The slope was not secured by any of masonry elements. In light of the fact that no documents of that time were preserved the slope gradient of $60^{\circ}$ has been assumed. Currently there is a road along the slope. Taking into account the fact that main roads do not change their location, the road along the scope has been also assumed. The load that affects the church foundations from the side of the bell tower wall has been adopted at the value of $765 \mathrm{kN} \cdot \mathrm{m}^{-1}$.

2. At the second stage (Fig. 4) - 1904-1907 - the foundations were strengthened by underpinning of the existing foundations by sections of the length of about $1.0 \mathrm{~m}$. The underpinning was provided with solid brick and lime mortar. The same time the retaining wall was built and fencing around the church area was installed. The solid brick wall on lime mortar survived up to 2010 . The load as at stage I.

\section{DETAIL OF THE SLOPE STAGE I}

\section{STATUS BEFORE 1904r.}

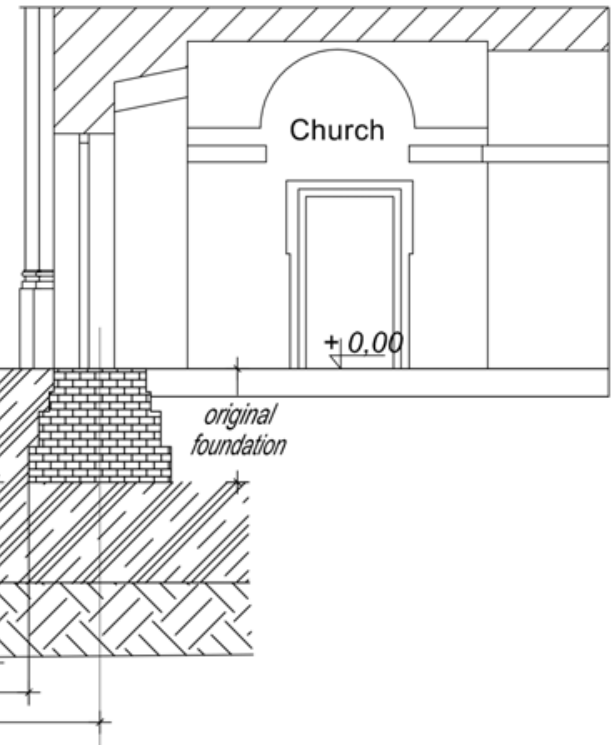

Fig. 3. The first stage - before 1904 


\section{DETAIL OF THE SLOPE} STAGE ॥

STATUS BEFORE 2010

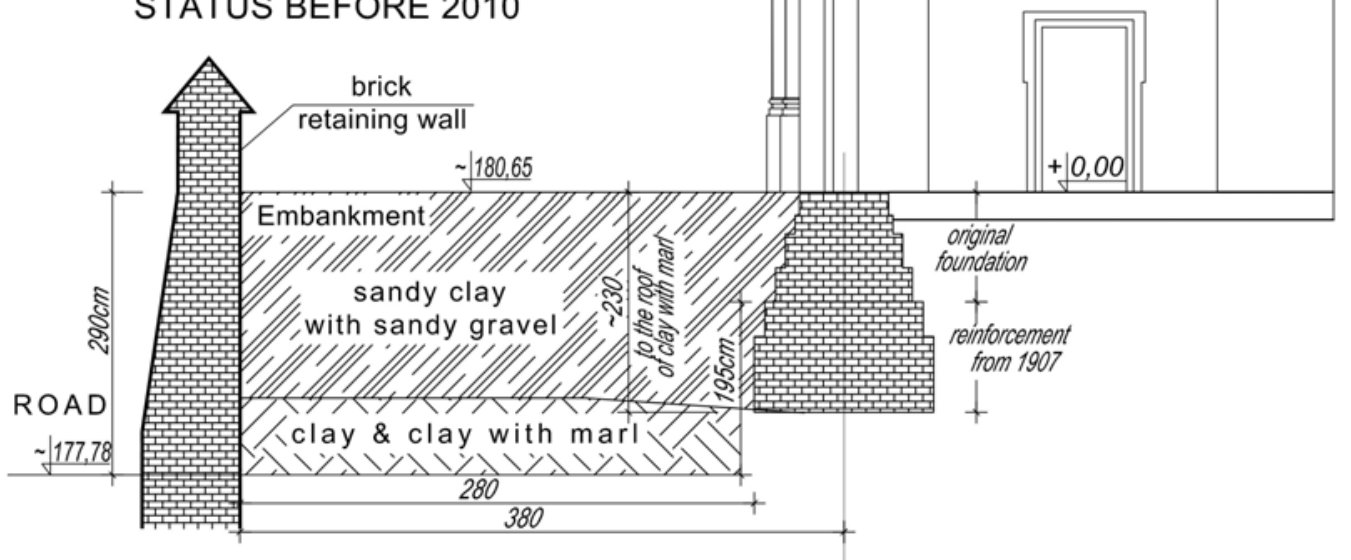

Fig. 4. The second stage - the status before 2010

3. At the third stage (Fig. 5) -after 2014-the retaining wall was strengthened by reinforced concrete coating around the existing wall that the retaining wall became more massive. What is more, it was reinforced with micropiles drilled in turns one from the church side and the other from the road side, every $0.5 \mathrm{~m}$ on average.

The soil parameters have been adopted in accordance with the tests (Pozzi et al., 2008) listed in Table 1.

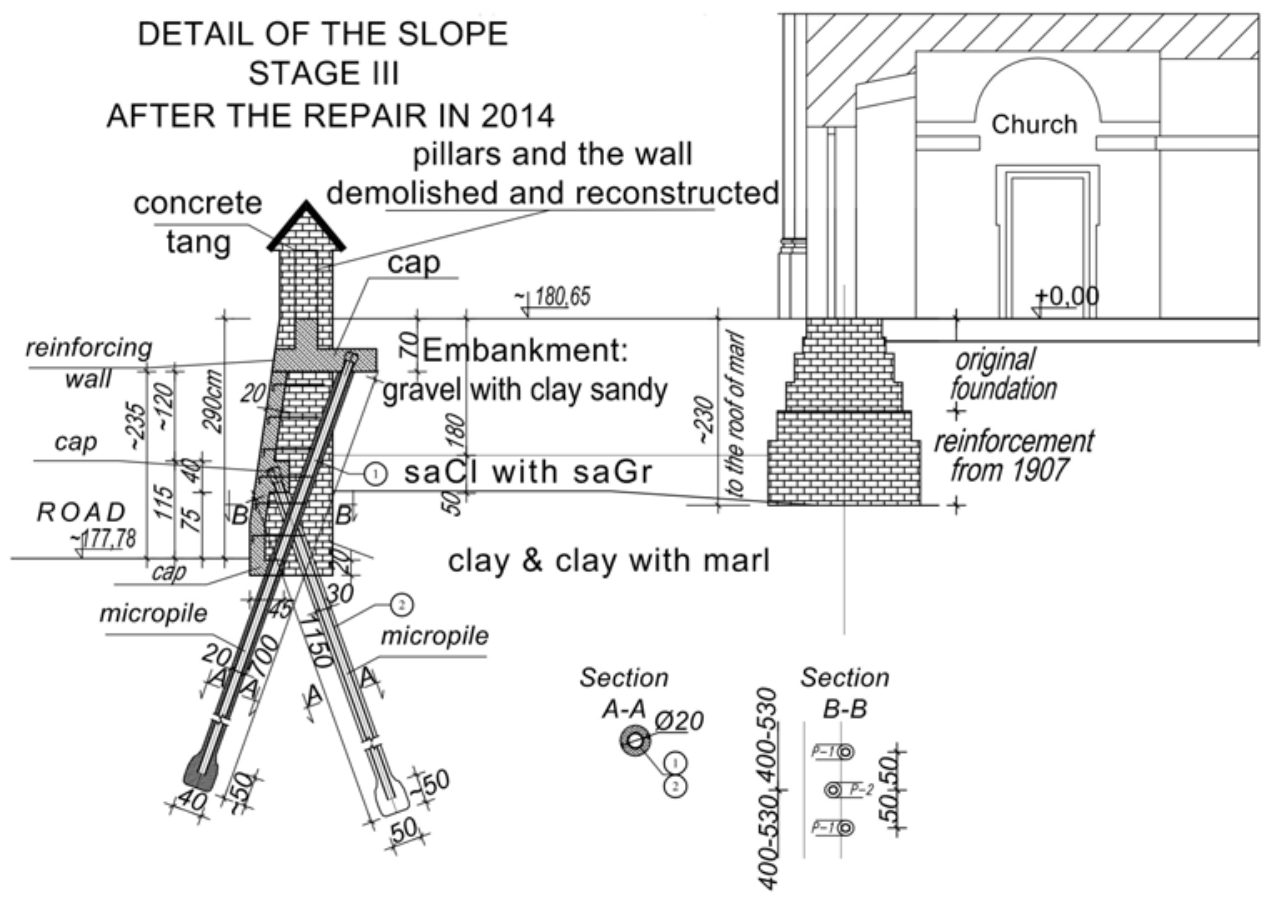

Fig. 5. The third stage - the status after the repair in 2014 


\section{CALCULATION METHODS}

By losing the embankment stability (slope) it is meant unlimited movement of the part of soil or rock mass adjacent to its surface resulted from exceeding the limit internal resistance against shear strength (Abramson, Thomas, Sharma \& Boyce, 1996) in various places. The task of verifying the embankment stability (slope) is the task that should be executed by means of calculations. The slope stability is calculated by using the equilibrium factor $F$. The factor serves to estimate the threat to embankment balance (slope) (Wysokiński, 2006), defined as the proportion of the generalized sum of maintaining forces activated by material shearing and coherence $U_{i}$ to the sum of generalized forces causing a slide $Z_{i}$.

$$
F=\frac{\sum U_{i}}{\sum Z_{i}}
$$

The $F$ factor from the formula (1) takes the following values:

$F<1$ - for an unstable slope,

$F=1-$ for a slope in moment equilibrium,

$F>1$ - for a stable slope.

In case of geotechnical structures a deformed area can be quite precisely determined and the values of the geological structures can be forecasted over time. On the basis of the geological and geotechnical tests the limits of the area in which deformation occurs is practically impossible to be specified. The good practice is to conduct visual check-outs after obtaining calculation results because only geodetic observations of premises may provide credible information on the scale of the deformed area.

In the paper it has been employed the comparison of the results of the stability calculations of the slope the church stands on. The results were obtained on the basis of the calculations conducted with the use of the limit equilibrium methods. The methods are frequently used by engineers because they are comprehensively described in the literature and they do not require complicated soil parameters. To the group of the limit equilibrium methods belong the following: Fellenius method (Swedish), Bishop's method, Janbu's method, Nonveiller's method, Baker and Garber method, Kenney's method, Mozewitinowa and Szynterminowa method, Morgenstern-Price method, Spencer's method, Madej's method (Abramson, Thomas, Sharma \& Boyce, 1996).

\section{CALCULATION RESULTS AND THIER ANALYSIS}

For further calculations it has been selected the ones that are most extensively described in the literature (Abramson, Thomas, Sharma \& Boyce, 1996; Wysokiński, 2006). All calculations were optimized in respect of the most dangerous slip surface to which the $\mathrm{F}$ factor was stipulated. The obtained factors of safety have been compared and juxtaposed in Figure 6 .

Following currently binding standards in order to declare slope stability the factor of safety F should be 1.5. The studies indicate that for such value the losses of stability of the existing slopes do not occur. Provided the factor obtained the value between 1.3 and 1.5 then such structure should be monitored on a continuous basis.

The first evaluation conducted in 1904 aimed at determining the causes of numerous cracks that had occurred on the church walls. In the stage I of the structural behavior that had been assumed (Fig. 7a), the average factor of safety for 5 methods was $F=0.684$, which means that the slope is not stable. The church building was settled on the slope of the height of about $1.25-2.70 \mathrm{~m}$ above ground level. Originally the structure had been settled only partially on natural soil and in the northern part on made soil. The fact that the slope had not been secured at the first discussed stage resulted in gradual deterioration of the church building. The location of the averaged slip surface in Figure $7 \mathrm{a}$ indicates that it penetrated just before and under the original foundation of the church. The foundation shift resulted from a slip line caused numerous cracks of the church vaults and walls, the reaction to which were attempts of preventing it by anchoring of the church walls.

The stage II of the discussed changes was conducted concerning deeper foundations and the slope prevented from sliding by the retaining wall built with solid brick and lime mortar (Fig. 7b). The loads of church roof, ceiling and walls and the road remained unchanged. Nevertheless, the average factor of safety 


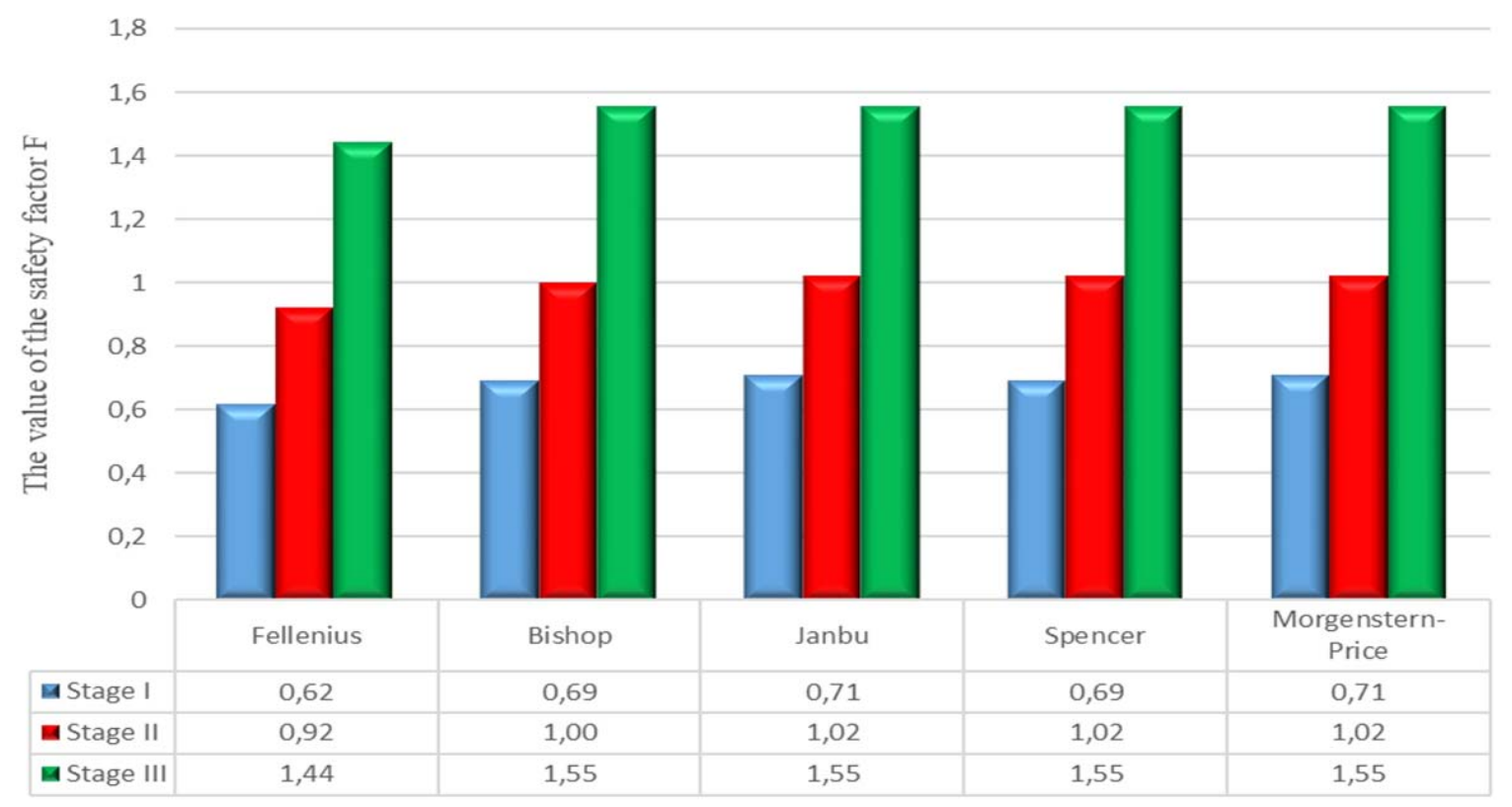

Fig. 6. Comparison of factors of safety in the respective stages of the structure "existence"

a

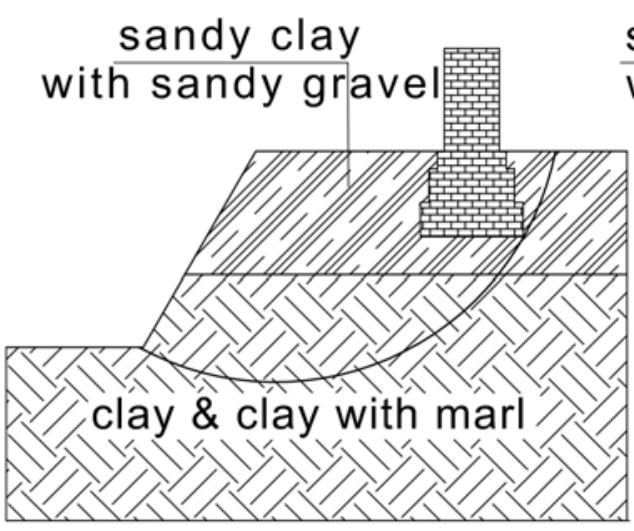

b

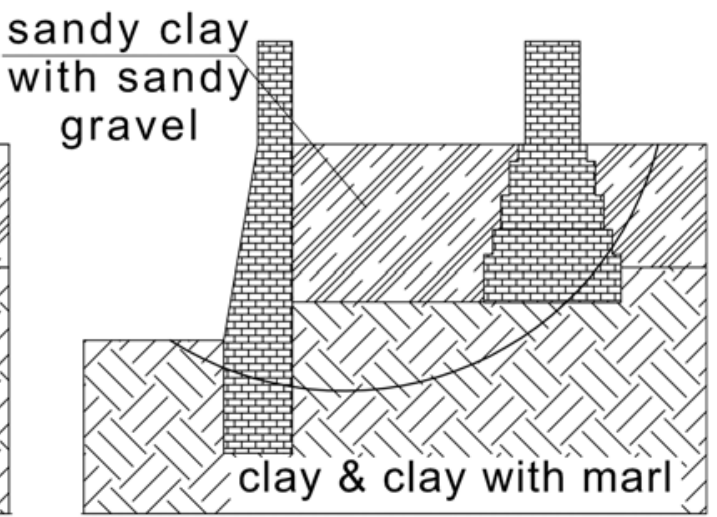

Fig. 7. Calculation model adopted for the respective stages of church settlement reinforcement: a - I stage before 1904, b - II stage the status as of 2010

for the slope was still 0.997. It shows that the slope remained unstable. After the reinforcement, the slip surface, which runs through the new part of the brick foundation reinforcement and the wall reinforcement, went down deeper. Maximum value of the total force of the horizontal impact exceeded calculation ground resistance for slip about $10 \%$. In spite of this, no changes were found in the construction of the wall and the embankment. The uncover during the wall repair indicated the presence of field stones in the foundation, the bearing capacity thereof cannot be estimated. The instability of the slope led to deterioration of the retaining wall (Fig. 8) and further gradual deterioration of the church, and new wall cracks.

The III stage of calculations involved the following changes: the retaining wall was strengthened by reinforced concrete coating as well as the pivot protruding from it on which the brick wall was reconstructed. The 


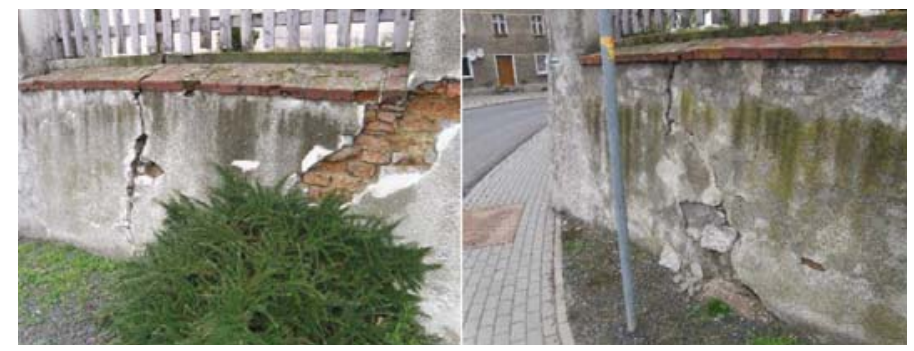

Fig. 8. Damage to the brick retaining wall (Bajno, 2014, photo by D. Bajno)

a

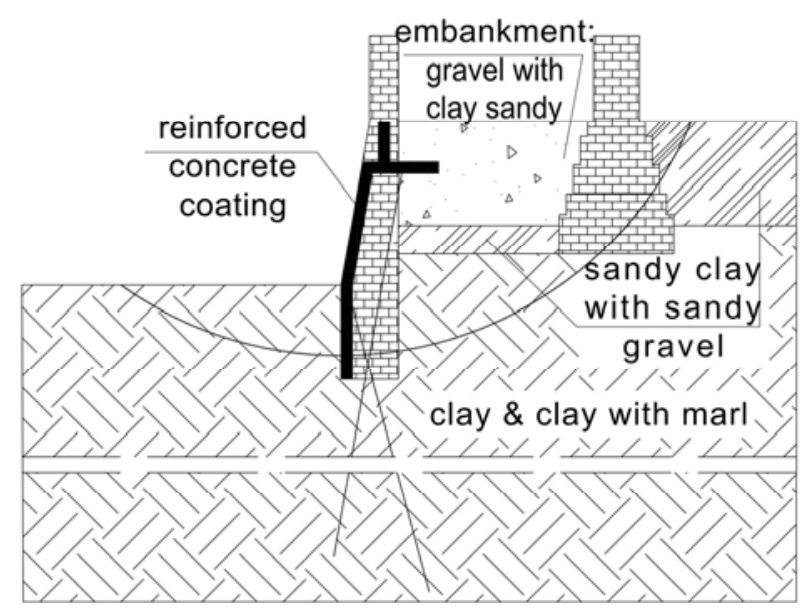

b

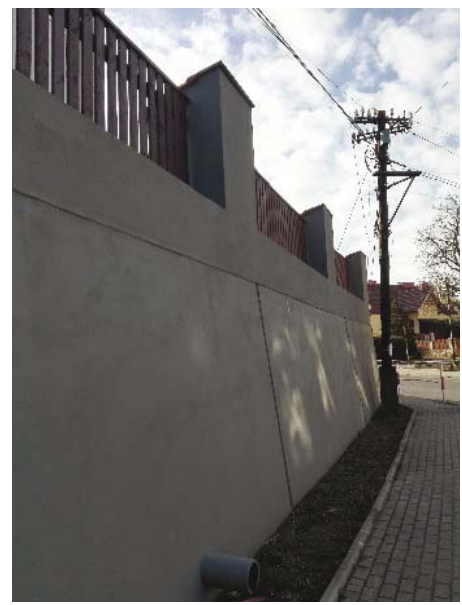

Fig. 9. Calculation model adopted for the respective stages of church settlement reinforcement: a - the stage after the repair in 2014, b - wall's view after the repair (photo by E. Kokocińska-Pakiet)

reinforced concrete coating was additionally anchored with two micropiles (Jurczakiewicz \& Kaczmarczyk, 2011), mounted onto the coating. The drilled micropiles were mounted in turns every $0.5 \mathrm{~m}$. One was $11.5 \mathrm{~m}$ long and its diameter was $300 \mathrm{~mm}$, the other one - the length of $7 \mathrm{~m}$ and diameter of $200 \mathrm{~mm}$ (Fig. 9a).

Between II and III stage one more change was introduced, chestnut trees around the church square were removed - 9 pieces, planted around the court (Fig. 1b). The impact the trees had on the building is difficult to determine and categorize. However, after cutting down the trees their roots remained in the slope mass. The embankment protection that was applied in the places where the brick wall had been cracked or corroded significantly improved the slope stability, the condition of which is additionally exacerbated by increased loading from the side of the Province road that runs at the base of the wall. The average factor of safety that was obtained is 1.528 . It falls within the standard limits. The slip surface estimated under the calculations runs through the original and reinforced foundation and through the base of the retaining wall and it ends at the Province road level. Such solution, however, requires continued observations whether further damage to repaired wall and church's wall will occur.

\section{CONCLUSIONS}

The III stage results are satisfactory, however, one should remain alert because the settlement of the discussed monument require further monitoring. The slope stability may be affected by various factors. The slope has been already protected but it is 
neighboured by the Province road with heavy traffic of trucks, which may adversely affect the slope stability. According to the recommendations (Pozzi et al., 2008) the outlet pipes discharging water from the church roof were repaired, which prevents the slope from soaking up. Meanwhile the chestnut trees, which prefer damp soils not wetlands and their root system is flat, just under the surface and widely spread out, were removed. However, it is a disadvantage that the root system of the cut down trees has remained. Presently, they do not pose a threat but decaying tree roots may trigger off deeper penetration of rainwater, which may impact the slope stability. The leaking stormwater drainage system has been repaired and the directions of the rainwater discharge have been put in order so the church walls do not soak up. However, instead of installing discharge pipes to the combined sewage system the solution that has been employed may result in soaking up of the retaining wall base (Fig. 10).

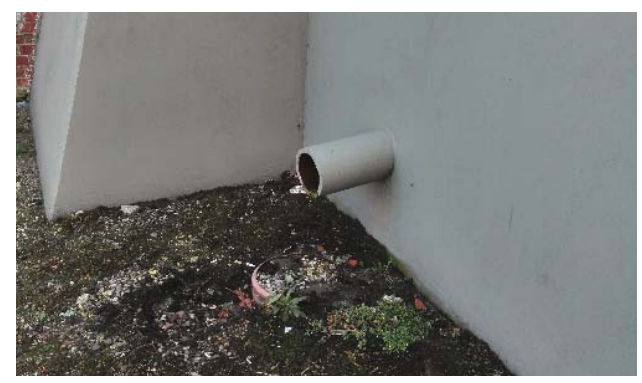

Fig. 10. Water discharge from the church square (photo by E. Kokocińska-Pakiet)

What should be borne in mind is the loading of the building settled on the slope. All repairing works conducted in the church must be monitored because they may affect the load planning of the building or the behaviour of the structure. The attention should be also paid to the behaviour of the building itself because its anchoring lacks adequate tensioning of the iron elements. No records have been found in source materials (Chronicle, 1907; Paluch \& Załęski, 1964) concerning the building anchoring at the foundation level. It is a factor that may have a negative impact on the structure of the building.

\section{REFERENCES}

Abramson, L. W., Thomas, S. L., Sharma, S. \& Boyce, G. M. (1996). Slope stability and stabilization methods. New York: John Wiley and Sons, Ltd.

Bajno, D. \& Bednarz, Ł. (2010). Kościół w Prószkowie na Opolszczyźnie jako przykład powtarzalnych wyzwań przy ratowaniu historycznych obiektów budownictwa sakralnego - badania, wytyczne konstrukcyjno-konserwatorskie. Wiadomości Konserwatorskie, 28, 49-60.

Bajno, D. (2008). Ekspertyza techniczna budynku kościoła, należacego do Rzymskokatolickiej Parafii p.w. św. Jerzego w Prószkowie. Opole.

Bajno, D. (2013). Rewitalizacja konstrukcji budowlanych w obiektach zabytkowych. Bydgoszcz: Uniwersytet Technologiczno-Przyrodniczy.

Bajno, D. (2014). Troska o zabezpieczenie i należyty stan techniczny zabytkowego kościoła św. Jerzego w Prószkowie. In A. Hanich (Ed.), Studia z dziejów Prószkowa. (pp. 138-153). Opole.

Central Statistical Office (2014). Kościót katolicki w Polsce 1991-2011. Roczniki statystyczne. GUS. Warszawa: Zakład Wydawnictw Statystycznych.

Chronicle of the Catholic elementary school in Prószków 1897-1907. (1907). Prószków.

Jurczakiewicz, S. \& Kaczmarczyk, S. (2011). Stabilizacja posadowienia zabytkowych budynków przy pomocy mikropali na tle doświadczeń praktycznych. Technical Transactions - Civil Engineering, 108(19), 127-138.

National Heritage Board of Poland (2017). Raport o stanie zachowania zabytków nieruchomych $w$ Polsce, 2017. Zabytki wpisane do rejestru zabytków (edited by M. Rozbicka), Warszawa. http://www.nid.pl/pl/

Paluch, M. \& Załęski, E. (1964). Orzeczenie techniczne dotyczace zaistniałych pęknięć elementów konstrukcyjnych budynku kościoła parafialnego w Prószkowie powiat Opole, Wrocław. Wrocław.

PN-B-04481 (1989). Grunty budowlane. Badanie próbek gruntu.

PN-B-04482 (1989). Przyrządy laboratoryjnego oznaczania wytrzymałości gruntów na ścinanie z zadaną płaszczyzną ścinania. Ogólne wymagania techniczne.

PN-B-04483 (1989). Laboratoryjne metody oznaczania wytrzymałości na ścinanie przyrządami z zadaną płaszczyzną ścinania.

Pozzi, M., Mizyk, T., Łozińska, M. \& Adamczyk, M. (2008). Opinia geotechniczna dla oceny warunków posadowienia Kościoła Parafialnego pod wezwaniem Św. Jerzego w Prószkowie. Gliwice: Instytut Geologii Stosowanej. 
Provincial (Opole Province) Manument Conservator (2016, lipiec 31). List of Opole Province monuments. (edited by WUOZ) Opole.
Wysokiński, L. (2006). Ocena stateczności skarp i zboczy. Instrukcja ITB 424. Warszawa: Instytut Techniki Budowlanej.

\section{ANALIZA WZMOCNIENIA FUNDAMENTÓW BUDYNKU HISTORYCZNEGO}

\section{STRESZCZENIE}

W chwili obecnej na terenie Polski istnieje 183192 zabytków wpisanych do rejestru zgodnie ze statystyką Narodowego Instytutu Dziedzictwa z dnia 31 marca 2014 r. (National Heritage Board of Poland, 2017). W wykazie podanym przez Wojewódzkiego (Opolskiego) Konserwatora Zabytków z 2016 r., na terenie Opolszczyzny jest 40 budynków lub budowli zabytkowych zagrożonych katastrofą budowlaną. Część z nich znajduje się w stanie wymagającym natychmiastowej interwencji konstrukcyjnej. Statystyki te są zatrważające, ale ze względu na różne stany własnościowe budynków oraz sytuację materialną właścicieli niestety naprawy nie są realizowane na bieżąco. Na podstawie dokumentacji geologicznej i budowlanej jednego z zabytków sztuki sakralnej województwa opolskiego przeprowadzono analizę posadowienia tegoż zabytku na przestrzeni wieków. Pierwsza faza obejmowała analizę zachowanie fundamentów pierwotnych kościoła posadowionego na skarpie. Druga faza obejmowała analizę fundamentu po wzmocnieniu oraz zabezpieczeniu skarpy murem oporowym z cegły. Ostatnia, trzecia faza obliczeń, objęła fundamenty konstrukcji po wzmocnieniu wraz z murem oporowym wzmocnionym płaszczem żelbetowym i palisadą z mikropali zakotwionych w murze. Skoncentrowano się głównie na metodach równowagi granicznej. Na podstawie wyników analiz oceniono stabilność skarpy i konstrukcji. Określono też proponowany kierunek dalszych prac konserwatorskich, aby budynek historyczny był przydatny dla przyszłych pokoleń.

Słowa kluczowe: zabytek, analiza posadowienia 